\title{
0 DRAMA DO CORPO ESCARNECEDOR A PERFORMANCE NA FESTA DO LAMBE-SUJO DE LARANJEIRAS-SE
}

\author{
Mesalas Ferreira Santos (Faculdade Pio X)
}

No mês de outubro, na cidade de Laranjeiras-SE, municipio situado a $23 \mathrm{~km}$ da capital sergipana, Aracaju, ocorre uma festa denominada Lambe-Sujo em cujo centro estão reunidos indivíduos que representam, de um lado, os antigos escravos - lambe-sujos - e, de outro, os chamados caboclinhos, representantes dos índios. Durante o dia festivo encenam um embate, do qual os negros saem derrotados. A imersão dos brincantes é de fundamental importância para o desenvolvimento festivo. As expressões performáticas, tais como o escárnio, a comicidade e o grotesco surgem como elementos significativos da cultura. Atualizo esse debate através das contribuições antropológicas acerca da performance e da noção de drama social na análise da festa.

FESTA, PERFORMANCE, COMICIDADE, ESCÁRNIO, CORPO. 
O galo anunciou com seu cacarejar que o dia começara. Os primeiros raios do sol atravessavam as espessas nuvens, trazendo consigo uma chuva fina que caía na relva dos vários morros que circundam Laranjeiras. Eram mais ou menos cinco horas da manhã, e as pessoas saíam na caminhada rotineira em direção à feira da cidade. O objetivo de ir tão cedo é encontrar os melhores produtos que serão consumidos durante a semana. Núcleo de maior centralidade na cidade, a feira também é local em que são encontrados vários produtos. Localiza-se entre o prédio do Centro de Tradição e o trapiche, onde recentemente foi construído o campus da Universidade Federal de Sergipe, um espaço amplo e de fácil acesso para todos os moradores.

Como a cidade não possui rede de supermercados, normalmente as pessoas vão à feira para abastecer suas despensas com produtos supostamente mais frescos e com preços mais baixos. No ato da compra, os moradores pechincham a fim de obter alguma vantagem na soma final e voltam para casa, carrinhos e cestas cheios com as compras da semana. Naquela manhã próxima à data da festa, a rotina dos moradores laranjeirenses que foram às compras foi interrompida por um rebuliço que chamou a atenção de todos os presentes.

\section{O ESMOLADO E A CONSTRUÇÃO DAS CABANAS: OS ANTECEDENTES DA FESTA}

Em meio a essas pessoas, em posição de destaque, surgiram duas figuras que destoavam completamente dos demais, ganhando a atenção de todos por onde passavam. Um negro retinto, de cor e brilho intensos, trajando calça vermelha na altura dos joelhos e gorro da mesma cor, guiado por um caboclo ornamen-

1. O esmolado consiste na saída de um membro de cada grupo, lambe-sujos e caboclinhos, com a tarefa de prover a alimentação dos grupos no dia festivo. $O$ negro acorrentado é 'subjugado' pelo índio e compelido a passar por todas as barracas dos feirantes arrecadando os alimentos necessários para a feitura da feijoada, distribuída no domingo. Com um cesto nas mãos e sendo tutorado pelo caboclo, o negro vai passando barraca por barraca interpelando as pessoas com frases como "dadá ioiô", e "vosmicê ajuda nêgo?". tado com exuberante cocar de penas de pavão, braceletes e tornozeleiras. Arco e flecha em punho e, na outra mão, uma corda que, amarrada na cintura do negro, impossibilitava sua fuga. Ocorria nesse momento, na feira de Laranjeiras, o esmolado ${ }^{1}$, marcando o início dos preparativos para a festa do Lambe-Sujo. Presente em algumas manifestações populares, o esmolado arrecada quaisquer doações. Em geral, os contributos coletados são gêneros alimentícios e dinheiro, o primeiro destinado ao almoço no domingo, uma feijoada, o segundo, normalmente repartido entre os que estão esmolando.

Inicialmente, eles passam pelas bancas de frango, carne bovina e, sobretudo, carne suína, sendo, em seguida, a vez de arrecadar o feijão, temperos, legumes e verduras. Nenhuma banca é poupada; todas as doações são aproveitadas, podendo facilmente ser encontrado no cesto utilizado na arrecadação até bolo de tapioca. A maioria dos feirantes ajuda, entendendo que esse ato estimula a continuidade do festejo, o qual se torna um meio difusor da cultura local. (Figura 1) 


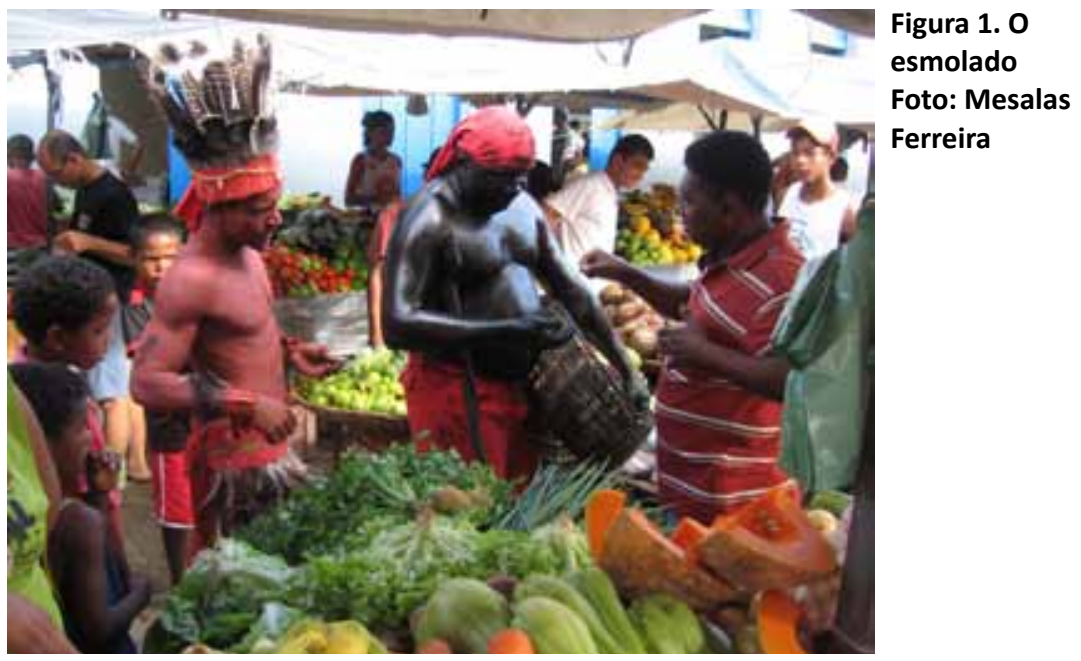

Ao postular o entendimento da composição da vida social por um constante dar e receber, Mauss (1974) mostra como universalmente dar e retribuir são obrigações organizadas de modo particular. O comportamento dos indivíduos na troca é reconhecido através de seu caráter voluntário, por assim dizer, aparentemente gratuito e livre, mas, no entanto, obrigatório e interessado. Nesse sentido, cada caso merece atenção, sabendo-se que a dádiva produz um estado de aliança, tanto na ordem matrimonial e política quanto na ordem religiosa, econômica e jurídica.

Daí a importância de entendermos como as trocas são concebidas e praticadas nos diferentes tempos e lugares, pois, de fato, elas podem tomar formas variadas, desde a retribuição pessoal até a redistribuição de tributos. Nesse sentido, as trocas incluem bens mais ou menos alienáveis, assim como bens economicamente úteis ou não - banquetes, danças, festas, gentilezas ou, até mesmo, mulheres; em suma, qualquer circulação de riquezas é apenas um momento de um contrato mais geral e muito mais permanente. Portanto, o objeto da dádiva do esmolado não é a economia, mas a circulação de valores (morais, econômicos, políticos) como um momento do estabelecimento do contrato social.

A sociabilidade criada pela dádiva do esmolado na festa do Lambe-Sujo conduz à apreciação do envolvimento de uma comunidade que, apesar de todos os seus problemas, investe parte de seus bens na realização do evento. Na verdade, esse envolvimento vai além do meramente dar; o dar é entrar em contato, permitir a comunicação entre os moradores, estimulando a sociabilidade e, a intersubjetividade. Os moradores doando seus pertences, no caso os alimentos, procuram de alguma forma mostrar seu vínculo com tal prestação, para que possam desfrutar posteriormente.

A feirante Maria das Dores, de 49 anos, natural da cidade, afirma que é quando os moradores doam o que têm de mais valor que se sentem copartícipes da festa, que, por sua vez, alimenta o sentimento de congraçamento entre os moradores. José Domin- 
gues da Silva, feirante, afirma que brinca na festa desde menino e que "as pessoas deveriam doar mais alimentos para que todos pudessem se empanturrar de comida no dia festivo". Nem todos, porém, pensam dessa maneira, e alguns, ainda que poucos, preferem não contribuir, alegando como motivo principal a violência gerada pela festa.

Após terem arrecadado todos os ingredientes que servirão para o preparo da feijoada, por volta das dez horas da manhã, levaram os alimentos para a casa do Mestre Zé Rolinha ${ }^{2}$ onde sua mulher iniciou a feitura do 'sustento'. É interessante ressaltar que no

2. José Ronaldo Menezes, mais conhecido como Zé Rolinha, mestre folclórico e líder de três manifestações culturais marcantes da região (Lambe-Sujo, Chegança e Batalhão) há 40 anos.

trajeto, no ato de levar as contribuições arrecadadas para a casa do mestre, é comum ocorrer a subtração de alguns produtos. $\mathrm{O}$ caboclo e o lambe-sujo escolhem e deixam guardados à parte os produtos de sua preferência; também os vigias da comida arrecadada na hora do esmolado apanham igualmente sua parte. Após deixar as doações na casa do mestre, o negro e o indígena voltam às ruas interpelando as pessoas a contribuir com qualquer quantia, sob a ameaça de melá-las com mel de cabaú caso a resposta seja negativa.

Por volta de uma hora da tarde, outros integrantes de ambos os grupos se reunem diante da casa do mestre, com a tarefa de ir à mata, retirar as taquaras que servirão para a montagem das cabanas dos grupos. Foices, calça jeans e botas são instrumentos indispensáveis nessa empreitada que requer muita atenção no percurso que apresenta muitas dificuldades tanto ao adentrar o espesso matagal bem como atravessar córregos de lama. Cerca de 15 pessoas entram na mata para pegar as taquaras (bambus) e, em conjunto, recolhem também folhas de pindoba (palmeira), imprescindível na amarração e na decoração da cabana. Todos procuram as mais vistosas visando deixar suas cabanas mais formosas e atraentes para quem chega à cidade a fim de conhecer o festejo.

O momento do corte das taquaras é marcado por relação hierárquica entre os integrantes dos grupos. As tarefas são divididas entre os varões - homens mais fortes, que portam as armas e são os responsáveis pela escolha e retirada das taquaras mais vistosas e pelos cuidados necessários para que ninguém se machuque na empreitada - e os menos encorpados, que não possuem tanta habilidade no corte das taquaras nem o conhecimento necessário à orientação dentro da mata; a eles cabem a obediência aos mais experientes e o transporte das pesadas e cortantes taquaras nos ombros. Essa hierarquia, vale ressaltar, é permeada nesse momento por uma relação jocosa entre as duas gerações.

Os menos experientes escutam galhofas dos mais velhos, principalmente com relação à escolha na participação do lambe-sujo. Frases do tipo "não faça corpo mole", "você não quis ser nêgo? agora mostre força" ou "olha que lambe-sujo molenga, não dá nem pro caldo" são comuns. A descontração toma conta do ambiente, e logo iniciam as conversas sobre como será a festa; o que será usado como adorno pelos integrantes; surgem apostas para saber quem se manterá de pé mais tempo sob o efeito da cachaça durante o dia festivo e quem tomará mais chicotadas ao desafiar os taqueiros. Terminado 
o processo de colheita das taquaras e das pindobas, os grupos se dispersam cada qual para seu local específico de construção das cabanas, que não podem ser próximas uma da outra.

Ao longo de dois quilômetros, os menos experientes trazem uma a uma cerca de 40 taquaras e incontáveis pindobas até o local escolhido para a construção da barraca, o Largo do Quaresma, que fica em um campo de várzea, utilizado para prática do futebol, localizado entre o Rio Cotinguiba ${ }^{3}$, a praça do Largo 3. No século XVIII, o Rio Cotinguiba servia como rota de chegada de escravos e escoamento de produtos da região. e o terminal rodoviário, ponto de intenso fluxo de pessoas. Ali, alguns integrantes dos grupos já iniciaram a construção cavando buracos no campo para colocar as taquaras. Verificam-se formas diferentes de construção nas cabanas dos dois grupos, valendo registrar o zelo na feitura da que pertence aos lambe-sujos.

Dispostas de duas em duas e amarradas na ponta, as taquaras tomam a forma de arco, sendo levantadas em seguida e colocadas nos buracos. Depois de suspensas, iniciase a amarração nas laterais para dar firmeza e sustentação e, por fim, a cabana é fartamente ornamentada com palhas de bananeiras e pindoba. No final da tarde finaliza-se o processo espalhando-se folhas secas na base da cabana que, no final da festa, será queimada. Perto dela é levantada a forca, destinada à execução do negro que trairá o grupo junto aos caboclinhos. Por fim, é garantida a presença da bebida, o combustível imprescindível de tal empreitada.

O local utilizado para a montagem da cabana dos caboclinhos é diante de uma escola de educação infantil, cerca de 500 metros afastada da cabana do grupo rival. Sua construção não obedece aos mesmos critérios de zelo, sendo dispensada qualquer medida de cuidado ou algo similar, despertando muitas vezes até má vontade daqueles designados para a montagem da estrutura. As taquaras são erguidas de qualquer maneira, a amarração feita de modo descuidado e nenhum adorno é colocado em sua estrutura, deixando, assim, a cabana dos caboclinhos com aspecto tímido em relação à construção dos lambe-sujos. É comum, aliás, o fato de alguns bêbados caírem de encontro às taquaras, desmontando a estrutura de frágil amarração que também, muitas vezes, não suporta os ventos, tombando por terra sem que ninguém a venha levantar novamente.

No início da noite a cidade começa a ter seu ritmo alterado em função da montagem de barracas na praça do Largo do Quaresma, onde ocorre o combate final. Os botecos, espalhados nos arredores da feira, com suas músicas de ritmo e letras insinuantes são os locais preferidos das pessoas que aguardam a festa, cuja sociabilidade se faz em torno da cachaça, bebida de cabra (CASCUDo, 1968, p. 75), que faz parte enquanto expressão cultural do cotidiano da maioria das pessoas presentes nos arredores da cidade.

As relações sociais dessa população são expressadas através do processo histórico e estão profundamente atreladas aos grupos sociais e à forma como manifestam suas angústias, seus desejos, suas conquistas, sua fé, esta materializada em determinado espaço, em rituais e festas. E, nesse sentido, a bebida sempre esteve presente, como forma de consolidar laços afetivos e sociais. O beber não significa meramente 'encher a cara', 
tendo antes cunho preparatório. Se, no cotidiano, o ato de beber pode parecer fuga à realidade opressiva, forma de esquecer momentaneamente os problemas da vida, na prévia do Lambe-Sujo significa aceitação do convite para a inserção na festa.

Os benefícios arrolados pelos que da cachaça já se serviram são inúmeros. Acreditam que ela faz lembrar os que 'já foram' e, antes do primeiro gole, é comum estabelecer as honras mediante oferenda - três pequenas porções despejadas no chão - aos antigos companheiros que de alguma forma auxiliaram na manutenção da festa ao longo dos anos. Sem dar tempo de alguma possível comoção se inflar no local, são lembrados inúmeros fatos chistosos de festas anteriores, na companhia dos amigos que não mais compartilham o prazer de beber uma 'caninha' na festa. Desta maneira, os fatos mencionados tomam conta do ambiente, clarificando que na celebração não perpassa seu entendimento através de provável relação com o passado colonial ou de possível ancestralidade, mas os momentos divididos com amigos, no desfrute de uma 'limpinha'.

O silêncio, juntamente com o sossego, forte característica da localidade no dia a dia, é rompido drasticamente a partir do cair da noite. No local circulam inúmeras motos que, nos dias normais, servem de transporte (mototáxi) aos moradores de localidades distantes, bem como de povoados vizinhos. A todo instante desfilam pelas pequenas ruas em velocidades impressionantes e com barulhos ensurdecedores, produzidos pelo escapamento alterado propositalmente para o festejo. $\mathrm{O}$ intuito, além de aleatoriamente agregar mais pessoas e produzir mais algazarra, é explicitar que aquela noite será diferente na cidade. Há também quem prefira ficar na calçada de sua casa, assando carne e bebendo cerveja com a família, sem muito alarde, afirmando apreciar o vai e vem de pessoas que chegam para conhecer além da festa a própria cidade. E, dessa maneira, seguem noite adentro, sem preocupação com horário de repouso.

\section{ALVORADA FESTIVA: A TOMADA DA CIDADE PELOS LAMBE- SUJOS}

A cidade pulsa à espera da alvorada. Como afirma Mestre Zé Rolinha, "ela não cai no sono, apenas pernoita". Por volta das três horas da madrugada do domingo o sino da Igreja do Senhor do Bonfim reverbera, rompendo com potentes badaladas o silêncio peculiar de uma cidade interiorana. A calada da noite dá lugar aos estrondos de carros, motos e das várias pessoas que andam em uma só direção, cantando e gritando nas ruas. 0 ponto de encontro é a casa do mestre dos lambe-sujos, uma casa verde, tímida, localizada na esquina da rua, que abriga também um comércio de bebida alcoólica. Em frente, na ocasião de minha observação, uma grande amendoeira abrigava algumas pessoas da chuva fina que caía, tornando a madrugada mais fria.

Logo, iniciam-se os toques dos instrumentos, e o volume de pessoas no local aumenta; encontramos adolescentes, adultos, idosos e até crianças, acompanhadas ou não. Na maioria são negros da própria localidade, semialfabetizados, moradores tanto da área urbana como dos povoados vizinhos e de diversas profissões: pedreiros, feirantes, garis, músicos, vigilantes, policiais; há também desempregados, que formam outra maioria en- 
tre os participantes. Trata-se dos integrantes do grupo lambe-sujo que, ainda não caracterizados, iniciam os toques dos instrumentos de percussão, recepcionando as pessoas com suas músicas.

A sonoridade produzida por timbal, cuíca, reco-reco, ganzá, pandeiro e cânticos entoados com força e vibração pelos tocadores, além de atrair mais pessoas ao local, proporciona um clima de euforia entre os presentes e informa à cidade, ainda recolhida, que naquele dia ela será tomada pelos negros. Ao som dos batuques, a interação dos participantes revela em algumas cenas o misto de escárnio e manha que perpassa todo o ambiente.

Nesse momento em que todos aguardavam, ansiosos, a saída do cortejo, uma situação ambivalente instala-se no local. Por um lado, aquela multidão, com os sentimentos aflorados, impondo suas subjetividades, totalmente imersa em suas emoções, cuja sociabilidade é mediada pelo excesso de pândega, causa certo temor aos desavisados. Entretanto, esse mesmo receio causado pelo estranho é a condição sine qua non, a peça que move a engrenagem da turba ensandecida, que lhe coopta as sensações e faz desarmar-se ante o desconhecido. Uma força invisível que impele os participantes a não orientar suas condutas conforme o estabelecido cotidianamente.

As performances dos indivíduos são guiadas e direcionadas mediante impropérios, escárnios, que, de maneira geral, provocam positivamente a excitação da turba. Através dessas ações performáticas os indivíduos mergulhados em suas subjetividades, no ato da representação de si, produzem o valor das coisas, demonstrando, assim, seu entendimento quanto à celebração da festa. Envoltos nessa dinâmica imposta pelas subjetividades afloradas, todos aguardam a saída de mestre Zé Rolinha que, em sua residência, faz as últimas orações rogando proteção a todos nesse dia. Os instrumentos silenciam subitamente, e ouvimos o propagar do som de uma voz fraca e tímida acompanhada, em seguida, por uma figura esguia e usando chapéu de palha que assoma à porta entoando versos, iniciando a alvorada festiva ${ }^{4}$.

Tava capinando, a princesa me chamou / Alevanta nêgo, cativeiro se acabou: / Samba nêgo, branco não vem cá, / Se vier, pau há de levar!

Ao chamado do rei dos negros, fogos são lançados de várias direções, informando o início da alvorada festiva. Gritos e euforia misturados com a repetição constante da música supracitada oferecem o ritmo que proporciona a cadência necessária na condução do cortejo. Este momento é reservado apenas ao grupo lambe-sujo, cujos componentes, ainda não completamente caracterizados, saem às ruas apenas com a calça, a gurita na cabeça e a foice de madeira em punho. A cada rua visitada, a intensidade das subjetividades aumenta forçando os indivíduos a extravasar mais suas emoções. Seguem cantarolando, acordando todos por onde passam, através da força rítmica dos batuques, seduzindo mais adeptos para o cortejo. Por volta de oito horas da manhã, o grupo vai até 
sua cabana, construída no dia anterior, adentra o espaço, e, nesse instante os instrumentos param de soar, decretando o fim da alvorada. Com a pausa, alguns brincantes vão à casa descansar para aproveitar melhor o dia; para a maioria, no entanto, a festa já começou e não tem hora para acabar.

\section{A CARACTERIZAÇÃO DO CORPO}

Momentaneamente dissipado, o cortejo, inicia a caracterização visual dos grupos, que ocorre de maneiras muito distintas. Revelando práticas e formas que em seu interior são percebidas na diferença, a demarcação 'fronteiriça' entre os grupos é demonstrada, inicialmente, através da pintura corporal. Embora os significados das cores na festa do

5. Material tóxico muito utilizado na pintura de residências.

6. É comum entre os informantes, a versão de que no passado esse mel era utilizado pelos escravos como forma de camuflagem em suas fugas.
Lambe-Sujo seja polissêmico, há uma interpretação mais geral, atribuída à cor tanto dos lambe-sujos quanto dos caboclinhos. A realidade é mais rica do que a supõem os olhos abertos. Além de nossa percepção cotidiana, dita normal, há outras que vazam a banalidade do mundo e revelam maravilhas e pavores ocultos. Não estão ali pela graça ou como objetos adiáforos, para tornar excêntrica a tradição. Nesse sentido, suas formas e cores, os materiais de que são feitos, suas quantidades e as disposições que Ihes são atribuídas possuem significados mais amplos.

Por toda a cidade veem-se pessoas, à porta das casas, iniciando o processo de caracterização. O grupo dos lambe-sujos é composto por moradores do município de Laranjeiras que cumpriram algumas exigências - ser aceito pelo mestre; ser cadastrado; ser natural de Laranjeiras; não se meter em nenhum tipo de confusão e cumprir as determinações do grupo -, que atestam a propriedade de sua presença. Para a caracterização, água, sabão em pedra e tinta xadrez ${ }^{5}$. O processo é simples, embora demande, inicialmente, o auxílio de outra pessoa, para passar a mistura desses três ingredientes por todo o corpo, deslizando por braços e pernas para reforçar as camadas até a epiderme ficar com aspecto fosco. Para finalizar passa-se o mel de cabaú ${ }^{6}$, obti-

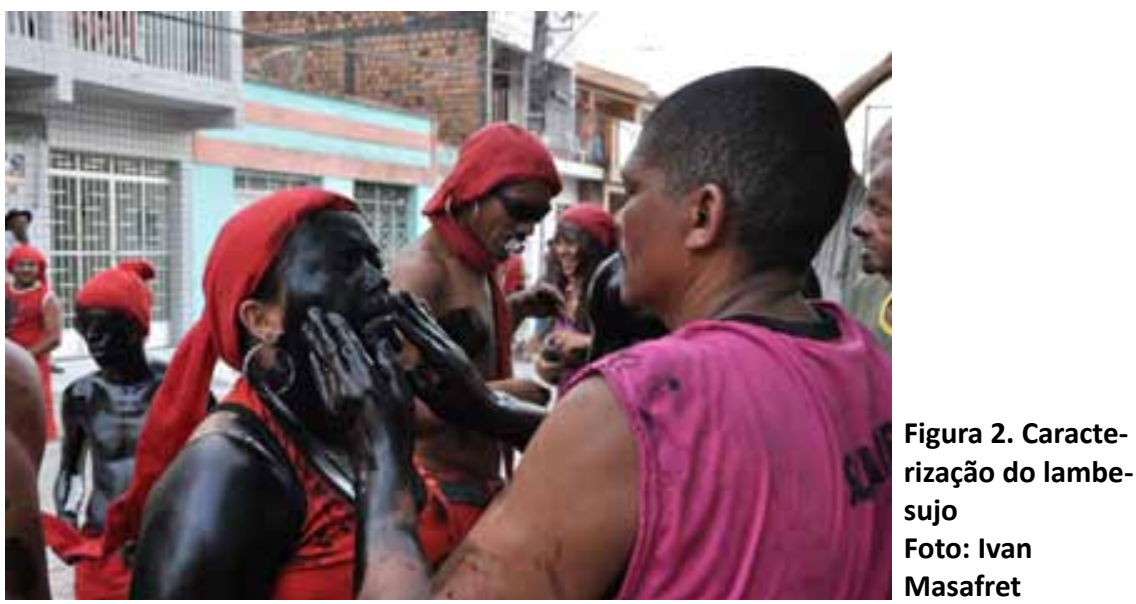


do na Usina Pinheiros e conhecido popularmente como mel de tanque, que garante aos corpos dos brincantes o aspecto de preto retinto. (Figura 2)

A indumentária utilizada é um calção vermelho feito de flanela e na cabeça um gorro da mesma cor, mas há quem prefira usar calça cortada à altura dos joelhos. Anteriormente, os grupos adquiriam os materiais das indumentárias e outros mantimentos por conta própria, realizando quermesses, bingos e outras atividades que geravam fundos através da arrecadação. Atualmente, parte do tecido é doada pela Prefeitura Municipal para a confec7. São cadastrados no grupo dos lambe-sujos cão de calças e guritas de todo o grupo. Trata-se, entretanto, de cerca de 200 brincantes. pouca quantidade para o grande número de integrantes do grupo $^{7}$. A distribuição é feita por Mestre Zé Rolinha, que se baseia no critério do 'auxílio', ou seja, quem ajuda nas tarefas da festa recebe alguns metros de flanela vermelha. Os demais adquirem por conta própria o material e colocam à disposição das costureiras para a confecção.

Como elemento de defesa, uma foice de madeira é permanentemente brandida no ar, simbolizando também o trabalho nos canaviais. Outros acessórios, como chupetas, cachimbos, óculos escuros, tênis, espadas de brinquedo, etc., costumam ser vistos, incorporando novos símbolos à festa. Essa estilização das vestes, em contraste com a cor negra dos corpos, que chama atenção pelo brilho singular, agrada aos brincantes que, devidamente paramentados, vão achincalhando pelas ruas da cidade, ao som da onça, do timbal e dos ganzás, cantando músicas próprias do folguedo.

A simplicidade das roupas e dos adereços não permite que sejam percebidos como fantasia. Essas vestes não são usadas para expressar fidedignamente um modo de vida, mas para veicular uma mensagem cujo significado fica intencionalmente restrito aos membros do grupo. A imagem dos diversos participantes traduz a clara intenção de demarcação de um traço identificador: indica quem pertence e quem não pertence àquele grupo e, portanto, compartilha um conjunto de referências, valores, princípios, comportamentos e atitudes - um dos meios mais externos e convencionais de definição dos diferentes papéis sociais na tradição.

$\mathrm{O}$ aspecto simbólico que envolve a cor preta é parte central nesse processo. $\mathrm{O}$ preto não só demarca relação com antepassados africanos, formadores da população local, como, no conjunto das pessoas visa atrair, prender a atenção, desafiar os sentidos. 0 preto assimila o escarnecer, a transgressão das normas, e ser lambe-sujo significa "não ter limites", "o tudo pode". Em conversa, o pedreiro José Antônio, que participa da festa há 22 anos, afirma que só é lambe-sujo por conta das possibilidades que representar esse personagem Ihe traz. Assegura que a experiência de participar desse grupo the proporciona inúmeras brincadeiras, ou como se fala, o 'tirar onda' com os demais, pois, em sua opinião, a história deve ser contada com "alegria, muita alegria para dar".

$\mathrm{O}$ caráter prescritivo da cor preta remete à valorização do negro enquanto ser oprimido, explorado e culturalmente desvalorizado ao longo de décadas. No entanto, o caráter performático, com a reação dos que com ela se deleitam, nos ensina conota- 
ção diferenciada. As reações sinalizam, de um lado, que o preto causa aversão e, de outro, que ele é o germe da agregação. Vimos, de fato, que algumas pessoas sentem nojo e medo ao se aproximar de um lambe-sujo, alegando, como levantamos, a sujeira imposta pela tinta em seu corpo, a dificuldade de remoção, o amedrontamento da animação exagerada, por exemplo. Por outro lado, a agregação se reflete nas possibilidades de atuação do lambe-sujo, que se integra pela corporalidade.

A ambivalência da cor preta demonstra "polarização de significado": o polo ideológico ou normativo, que se refere aos componentes da moral e da ordem social, bem como aos princípios de organização social, e o polo sensorial, diretamente relacionado com o entendimento que os brincantes têm de si. Portanto, um único símbolo dominante compreende tanto uma necessidade natural, como uma necessidade social voltada para o emocional. Toda essa agitação, esse regozijo popular necessita ser externalizado; é preciso estabelecer a práxis, o exercício prático da exultação da tradição.

O corpo é o canal que concentra as ações, a cor externalizada, a força motriz que gera a engrenagem festiva, cuja história é dramatizada via marcadores simbólicos irreverentes. Afirma José Carlos da Silva, morador e brincante há 28 anos, que o importante é,

8. Uso comum que significa pouco jeito para as tarefas sérias, em geral encarando as situações na brincadeira. além de poder fazer tudo o que de costume não faria, mostrar que "quando eu me melo eu me visto para brincar, para festejar minha origem e para fulerar; nós somos é fuleros, nego é fulero; é por isso que tira onda" ${ }^{8}$. Ao colocar a tinta preta no corpo, a intenção dos integrantes é celebrar sua tradição mediante expressões corporais irreverentes, cheias de vida; com a impulsionante e atestadora força que ordena os corpos rumo ao imponderável. Portanto, ser lambe-sujo perpassa aceitar a 'irracionalidade' das ações.

Esse formato de encarar a festa não significa afirmar a forma simples de exercer situação efêmera ou alegria fugaz que, possivelmente, energizará ou apaziguará os ânimos inquietos produzidos no contato com a vida cotidiana nem entendê-la a partir da noção de transgressão, através da violação da normatividade social. Nesse contexto, porém, vejamos o que os atores entendem no festejar o Lambe-Sujo. A cor imposta à pele faz os indivíduos compreenderem e estabelecerem a noção de ser lambe-sujo, principalmente ao enfatizar as ações mediadas pelo corpo ou, melhor, como esse corpo, a partir de referenciais simbólicos considerados 'irracionais', delimita e nos informa a relação do escarnecer, mostrando o vigor do ritual que leva os indivíduos a pensar sua sociedade, provocando-os a refletir sobre os valores fundamentais de sua ordem social e cosmológica.

Mais adiante, processo similar ocorre precisamente dentro da cabana dos caboclinhos. $O$ grupo é composto em sua maioria de crianças, mas também conta, em número escasso, com homens e adolescentes que fazem o comando hierárquico do grupo através dos personagens do rei, seu filho e a rainha dos indígenas. $\mathrm{O}$ tom avermelhado, conseguido pela mistura de água, tinta xadrez vermelha e sabão, é sinal distintivo entre os jovens. Os próprios moradores confeccionam as vestes dos caboclinhos: calção encober- 
to por saiote, capacete, punhos e tornozeleiras, tudo enfeitado com penas de aves da região; arco e a flecha complementam o visual dos caboclos - categoria social que emerge do encontro de brancos e índios - que realça seu lado indígena e guerreiro.

O vermelho, além de ser compreendido como guerra, o derramamento de sangue imprescindível na resolução de conflitos, é também visto como tom sério, que serve à demarcação simbólica da austeridade. O respeito à tradição demanda esforços rigorosos, que se caracterizam pela formalidade e seriedade na representação. Os caboclinhos não se consideram irresponsáveis ou desajuizados, muito menos dissimulados, qualidade que atribuem aos lambe-sujos. Estão destinados a cumprir metódica e disciplinadamente a ordem dos fatos. Nesse caso, a cor vermelha encontra respaldo na forma rígida de atuação corporal dos integrantes. O garoto Carlos André, brincante há cinco anos, afirma que não tem coragem de participar do outro grupo por conta dos "atropelos e doideiras" que os lambe-sujos praticam. O vermelho também é visto em oposição ao preto quanto ao caráter "sujo" que esta última cor insinua. Pedro Celestino, brincante há 11 anos nos caboclinhos, afirma que não tem vontade de participar dos lambe-sujos por conta da tinta preta que, em seu entender, denota "sujeira sem fim". (Figura 3)

Dois pontos chamam a atenção com relação os caboclinhos: o número reduzido de integrantes, em comparação aos lambe-sujos, e o fato de ser composto, em sua maioria, por crianças. Com característica mais soturna, contrastada com a euforia dos negros, os caboclos saem às ruas marchando ao som de caixas e tambores. Os passos firmes e a rígida expressão facial dão o tom disciplinar das ações. Com semblante sério, os caboclos procuram intimidar através de versos como "Preto correu, caboclo pegou" e "Rei dos caboclos prender nêgo", e seu cortejo percorre as ruas da cidade com a rigidez de soldados se preparando para o combate.

Os símbolos das cores no ritual festivo fazem parte de um processo em curso, cujas etapas sucessivas são dramatizadas nas performances dos indivíduos, na passagem de uma fase a outra. Todavia, as cores têm uma importante função de espelho da socie-

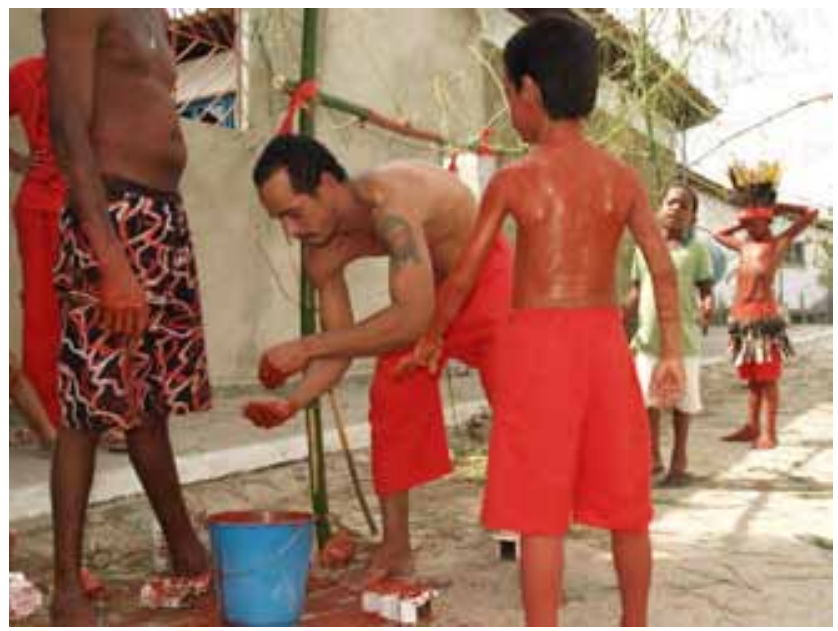

Figura 3. Caracterização dos caboclinhos Foto: Ivan Masafret 
dade e, nesse sentido, envolvem significados múltiplos, dando unidade à moralidade da ordem social e às necessidades emocionais do indivíduo.

Cada grupo tem seu comportamento apropriado e particular; o índio é o caçador, representante do lado vencedor das batalhas, e o negro, a caça. No meio tempo em que não se está nos cortejos nem nas embaixadas, caso um caboclinho capture um lambe-sujo, este se torna cativo, entregando o dinheiro que tiver consigo. Amarrado a uma corda, se vê obrigado a pedir esmola para o índio em prol de sua soltura.

Esse ritmo metódico contrasta com a animação dos lambe-sujos, que cantam, dançam, esmolam e, sobretudo, melam as pessoas com o mel de cabaú. Esse comportamento impertinente pode ser apreendido como mais um elemento distintivo e de oposição entre os grupos. Os lambe-sujos têm na irreverência um caráter identificador e, ao externar essa característica, inserem performances, dando lugar a cenas no mínimo curiosas.

\section{PERFORMANCE E ESCÁRNIO}

É chegado o momento no qual cada grupo sairá de sua cabana a fim de, liderado por seu príncipe, percorrer as ruas da cidade entoando canções. Os caboclinhos, liderados pelo filho do morubixaba, caçam os negros com o intuito de aprisioná-los. Na condução do préstito do lambe-sujo, o príncipe tem a tarefa de proteger seu povo de possíveis forças exógenas que ameaçam o quilombo. A sonoridade dos instrumentos musicais, somada ao repertório de malícia executado pelos percussionistas, faz as pessoas levitarem num bailado de cores fortes.

Quatro personagens conduzem o cortejo; são os taqueiros ou feitores. Trajam calça e camisa de flanela vermelha, colete de couro com adereços e seguram taca de couro; lembrando os vaqueiros com gibão e chapéu de couro, no enredo festivo e na história local representam os antigos capitães do mato que, junto com o gentio apaziguado, caçavam os negros foragidos dos engenhos de açúcar. Na prática, porém, as ações destinam-

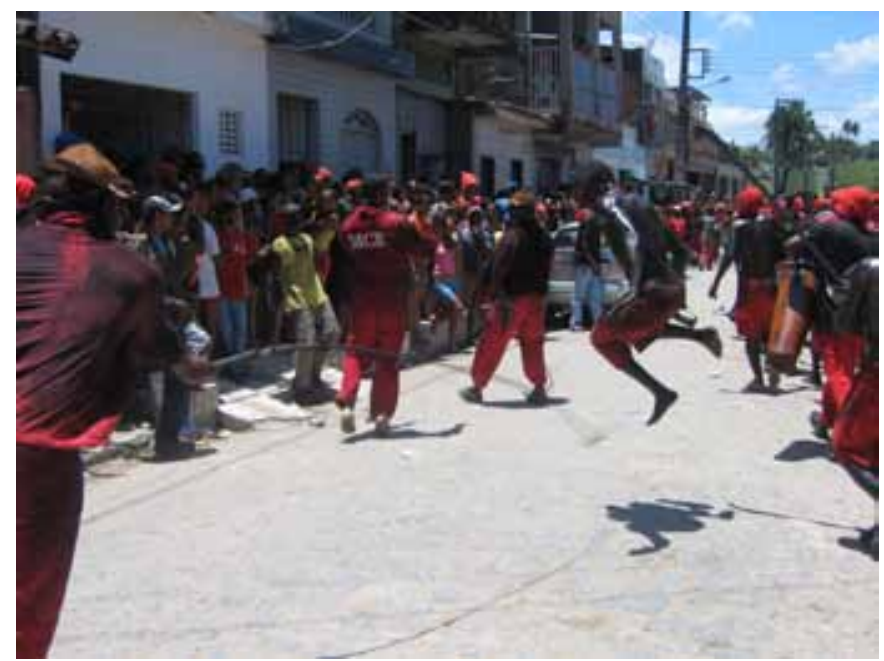

Figura 4. Performance do taqueiro Foto: Mesalas Santos 
se a outra interpretação. O que se vê, é o taqueiro conduzir a evolução do cortejo da meIhor forma possível. (Figura 4)

No intuito de disciplinar os negros inquietos, têm a função de organizar, infringindo dor com seu chicote, não deixando os negros saírem e nem os brancos entrarem no espaço destinado à evolução do cortejo. É interessante ressaltar que muitas pessoas no calor da folia entram nesses lugares proibidos desafiando o taqueiro que, sem comiseração, distribui várias chicotadas não importando em qual parte do corpo será desferido o golpe.

A história revela que os taqueiros ou, como são mais conhecidos, os capitães do mato estiveram entre os inimigos mais próximos dos escravos, pois, o fato de serem negros e de descendência africana facilitou sua colaboração para o aprisionamento e o tráfico de compatriotas para as colônias ibéricas fora da África. Na festa, entretanto, a normatividade que regula e orienta os sentidos, de certa forma, conduz a novos meios de interpretação. Sua função é proteger o grupo lambe-sujo das irreverências próprias do grupo; por isso as pessoas, mesmos as caracterizadas, que não estão dentro do perímetro do cortejo e que desafiam sua evolução são consideradas entraves. Ao desafiar o taqueiro, entrando e saindo do espaço destinado exclusivamente aos lambe-sujos, estabelecem uma relação jocosa entre espectadores e brincantes. Neste sentido, o negro é representado dramaticamente mediante a ação corporal ou, melhor, o corpo atuando a partir do escárnio.

Festas folclóricas, festas de rua, celebrações e rituais não são simplesmente expressões de sentimentos religiosos e espirituais; muitas vezes apresentam aspectos contraditórios e conflitantes da realidade, e em alguns casos descambam para a violência física. No intuito de controlar as emoções afloradas, as subjetividades fluindo no contexto festivo, os taqueiros produzem cenas interessantes. Seu chicote de couro cru dias antes é deixado de molho em óleo para alcançar a resistência ideal de instrumento utilizado para infligir dor e estabelecer a ordem no espaço. Com rápidas e potentes chicotadas, o taqueiro vai abrindo espaço. O movimento produzido faz ecoar o som dilacerante que corta o ar à procura do corpo escarnecedor e, desse encontro, resulta a abertura de sulcos profundos na pele, de onde goteja o sangue até encontrar o chão.

A ação causa repulsa e indignação aos corações ingênuos e nostálgicos dos mais antigos, que afirmam não existir tal situação em festas acontecidas em outros tempos. A maioria das pessoas que participam da festa, entretanto, excita-se com o açoite disciplinar do taqueiro. Muitos se preparam para tal feito, sobrepondo grossas vestes com o intuito de se proteger das tacadas e com ar desafiador agem com ações performáticas em torno de achincalhes, escárnios e insultos verbais, no intuito de se deliciar ao simplesmente receber um golpe de suas mãos.

Ao ser chicoteado o indivíduo se revigora, sente-se vivo, preparado para a experiência festiva, que representa mediante o esgotamento corporal, enfatizando sobretudo sua inscrição na própria cultura. A performance desenvolvida pelo taqueiro, no intuito de provocar a ordem, a disciplina dos brincantes é, do mesmo modo, uma das engrenagens 
que movimenta a festa. Em outras palavras, mais importante do que o acabamento formal do ritual é a intensidade de sua execução.

Tanto nos momentos que antecedem os cortejos e as embaixadas como ao longo de todo o dia festivo, nas pequenas ruas da cidade, as ações dos lambe-sujos contrastam com as atitudes dos moradores não caracterizados que, em sua maioria, são compelidos a fornecer alguma contribuição, que costuma reverter-se na compra de bebidas alcoólicas, estímulo visceral das emoções. Os transeuntes, desavisados, são abordados com a frase "dada, ioiô" e melados caso a resposta seja negativa. Nessa ocasião, a performance desenvolvida pelos negros pauta-se na necessidade de contribuição para adquirir alforria. Para tanto, lança-se corporalmente em gestos e atitudes próprios, procurando, assim, intimidar a vítima, que busca sair incólume da situação.

Há uma negociação entre as partes envolvidas. O negro inicialmente se aproxima, uma foice na mão e a outra estendida, apreensivo e atento às investidas dos caboclos, e, com palavras respeitosas, pede ajuda. A vítima, inocentemente, afirma que nada tem a oferecer, que não está com dinheiro algum no momento. Então o tom da fala muda, e o negro já começa a usar da malícia, afirmando que a pessoa "tem

9. Por volta da década de 1950 era comum o "saque" - os lambe-sujos "roubavam" pequenos objetos, e os donos teriam que dar um "agrado" ao grupo. Isso era realizado em pleno acordo, posto que a tradição é do conhecimento dos habitantes da localidade.

10. Expressão local para se referir a alguma homenagem reservada a algo ou alguém. posses e não se importaria em contribuir com um negrinho fuleiro". Nova recusa da vítima, agora com a voz mais inquieta. Radicalmente, muda a investida do negro, que passa a escarnecer com pequenas passadas de dedos melados de cabaú no rosto da pessoa, podendo estender-se ao resto do corpo, até conseguir dinheiro. A vítima, acuada e não querendo participar da melação, se sente obrigada a contribuir e, rapidamente, arranja dinheiro, sendo então solta; logo a frente, entretanto, encontra novo grupo e, assim, inicia nova negociação dramática.

Na parte final da manhã, a turba ensandecida dos lambesujos desloca-se para o terreiro nagô (DANTAS, 1988), mostrando o caráter religioso presente no festejo, bastante respeitado na localidade. Todos permanecem em silêncio diante do terreiro, para receber a bênção da ialorixá da casa visando à proteção dos negros naquele dia já que o combate será inevitável e se avizinha.

Mestre Zé Rolinha informa que esse momento é de extrema devoção e respeito, pois tanto o terreiro quanto o grupo possui ligação com as raízes africanas e, assim sendo, merece um "cortado de jaca"10. Apesar de não manter ligação com o terreiro e não seguir os preceitos religiosos da casa, Mestre Rolinha não se abstém de lhe prestar honrarias, dedicar salvas e vivas à religião afro e seus personagens, como, por exemplo, o preto velho, representado na festa pelo personagem Pai Joá, que na parte da tarde, ali no terreiro, será incorporado ao brinquedo.

Depois de abençoada, a turba novamente incorpora o "mana" escarnecedor e, em seguida, dirige-se à praça central da cidade onde se localiza a Igreja Matriz Sagrado Coração de Jesus. Reunem-se nos degraus das escadarias lambe-sujos e caboclinhos, 
à espera do pároco principal da região. Dispostos em lados opostos, ensaiam momentos de comicidade e insultos mútuos, tendo na cor e na expressão corporal os principais meios para alcançar seu objetivo: "Saia daqui, seu sujo; tem que estar limpo para chegar na casa do Senhor", afirma, de passagem, um caboclinho. E o lambe-sujo retruca: Eu não; quem deve sair daqui são vocês, sem graça. Sou sujo sim, mas carrego a alegria de viver".

Nesse meio tempo, entre um achincalhe e outro, as portas se abrem e, de lá, sai o eclesiástico todo paramentado de branco, pronto para celebrar breve missa. Interrompem-se o som dos tambores e o jogo insinuante e envolvente dos corpos que se expressam mediante situações irrealizáveis no cotidiano. Lado a lado no alto das escadarias, os dois príncipes oram em voz alta para a multidão que, sob o sol escaldante e a forte umidade acompanha as orações com empenho e devoção. Logo, mais bênçãos são distribuídas, e respingos de água benta caem sobre a cabeça dos mais próximos. Feita as preces necessárias, o padre é "melado" com a tinta preta e mel de cabaú pelos lambesujos, e, em seguida, sob os olhares vigilantes dos caboclinhos, todos deixam o local, impondo a marca das mãos nas paredes dos domicílios e dançando à sonoridade envolvente das músicas.

Ao se aproximar o horário do almoço, caboclinhos e lambe-sujos vão comer a feijoada arrecadada no esmolado. Na cozinha, as mãos habilidosas da cozinheira controlam a lenha no fogão para garantir a fervura ideal ao panelão de feijão já temperado que foi cozido com carnes de porco, linguiça, paio, charque, toucinho, etc. e, como se usa no Nordeste, legumes. No momento em que é servido o almoço, a algazarra é geral; os brincantes se amontoam e, entre o abanar dos pratos e brincadeiras licenciosas, chamam a atenção dos que servem a comida. Vencida essa etapa, procuram uma sombra fresca para descansar enquanto comem, sem talher, a feijoada que lhes garantirá o vigor para as atividades da tarde.

O tempo do repouso é o momento em que inúmeras situações são comentadas pelos participantes. Avaliam toda a estrutura da festa; como foi desenvolvida a parte da manhã, a evolução do cortejo, os problemas que porventura surgiram são passados a limpo no intuito de contorná-los para que não ocorram na parte da tarde, entendida como o clímax do evento. Além dessa avaliação de ordem estrutural as conversas giram em torno das peripécias desenvolvidas pelos brincantes.

Os comportamentos praticados nas ruas da cidade, palco principal de atuação, são meticulosamente arquitetados enquanto os "bolinhos"11 são levados à boca. O intuito principal é arriscar-se em aventuras em que o permissivo é o regulamento. O que mais importa gira em torno das brincadeiras, dos vexames impostos e das dores infligidas pelo azorrague do taqueiro, bem 11. A feijoada misturada com farinha, até formar uma massa, que é consumida aos punhados, em geral no formato de um pequeno bolo. como a licenciosidade das palavras e dos gestos.

Logo após o descanso do almoço, por volta das duas horas da tarde, nova concentração, agora com maior número de visitantes que acorrem à cidade para participar da parte final do festejo. Acrescentam-se também a presença de novos personagens e o 
combate final. $O$ forte ressoar do batuque seduz os súditos, convida a juntarem-se num bailado único, uma massa negra ansiosa para "vadiar". A turba, ávida, desloca-se com malemolência, transbordando emoções, vivendo intensamente o evento, clamando com cânticos, em direção à casa do rei dos lambe-sujos, onde aguardam sua saída.

O rei dos negros, ao desfilar entre os integrantes do grupo, exibe a pompa da realeza, revelada através de sua indumentária dourada composta por calça de tecido $d u$ chese vermelho, coroa de papelão dourado, peitoral de espuma de borracha e enfeitado com medalhas, pequenas bonecas e correntes douradas, e sua espada prateada. Ao lado de seu filho, conduz o préstito em direção, mais uma vez, ao terreiro nagô, onde, entretanto, não será realizada nenhuma prece, mas a agregação de Pai Joá ao cortejo.

A caracterização do Pai Joá simula o personagem preto velho: calça e blusa esbranquiçada, longa barba branca, chapéu de palha e cachimbo pendendo dos lábios. Seu lado místico reserva-lhe a função de proteger o grupo com seus feitiços. Dançando com muito gingado, junta-se aos demais membros do cortejo e segue pelas ruas da cidade atraindo curiosos com seu bailado. Cabe ressaltar que cantam com sensibilidade e excitabilidade; com a alma e com o corpo. Alguns emitem sons guturais e esganiçam intencionalmente. $O$ valor artístico surge desse mosaico de diferentes notas e vozes graves, médias e agudas. Em quase todos os momentos, o vínculo da musicalidade com as letras aliado às danças é de extrema relevância na concretização do ritual festivo. Com as cantorias e muita balbúrdia os lambe-sujos vão seguindo em direção à casa de outro personagem, Mãe Suzana, última parada do cortejo antes do confronto com os caboclos. A negra traja vestido estampado, pano envolvendo a cabeça, carrega um cesto cheio de objetos utilizados na cozinha como panelas, talheres, etc., e de brinquedos, simbolizando a escrava mãe que foge com os negros para ajudá-los no quilombo.

Sua qualidade mística não impede o aparecimento de um extravasamento corporal através de sedutor gingado. A única representante feminina do grupo traz em sua dança, agressiva e sensual, o incremento que faltava para fortalecer os demais na grande investida. Com as "cadeiras" requebrando freneticamente, estimula uma força imanente nos indivíduos, produzindo um estado de inquietação moral, uma "efervescência" escarnecedora. Com igual intensidade, o coletivo mergulha no embalo cada vez mais possante

12. É unânime a opinião dos participantes do grupo em diferentes posições e funções: na representação da Mãe Suzana a pessoa deve saber "remexer os quartos", em alusão a movimentarse sensualmente e com bastante molejo no corpo, pois assim "os negros brincam mais a festa". do som que reverbera dos instrumentos. Em conjunto perfeito, as interações produzidas fazem surgir o caos, o embalo estonteante a estremecer a turba, que retribui cantando melodias, saudando a integrante ${ }^{12}$.

Oia a nêga cum brinco na urêa / Essa nega ta danada / Tá cum brinco na urêa / Essa nega vai pra fonte, vai cum brinco na urêa / Essa nega vai lavar, vai cum brinco na urêa / Essa nega vai namora, vai cum brinco na urêa /

E, também:

Cadê Mãe Suzana, ô Suzanê! / Mãe Suzana morreu, ô Suzanê! / Tá no oco do pau, ô Suzanê! / Tocando berimbau, ô Suzanê. 
Reforçado por suas principais figuras - o rei, o príncipe, o Pai Joá e a Mãe Suzana - o cortejo dos lambe-sujos sai às ruas da cidade guiado pelos taqueiros que também assustam e até atingem com seu chicote, chegando às vezes a machucar, os espectadores que estiverem no caminho. Este momento da festa é marcado pela mistura dos corpos, sem que haja separação ou diferença entre espaço destinado aos lambe-sujos e o público. A todo instante integrantes do lambe-sujos invadem as calçadas e entram nas casas para melar as pessoas, bem como provocar sensualmente seus corpos simulando atos libidinosos. Nesse sentido as pessoas sentem e assimilam em si mesmas o cosmos festivo, com seus elementos naturais, nos atos e funções eminentemente materiais do corpo mediante o riso, escárnio, os insultos verbais e a sensualidade.

Muitos vão à festa preparados para levar o "manguá" dos taqueiros, que são constantemente desafiados. Para conseguir chamar a atenção, criam inúmeras maneiras de provocar a ira do azorrague. Fazem toda a espécie de insultos verbais, chegam até a desafiar a honra e a moral de quem domina a arte de infligir a dor. Logo o pedido é atendido e, de repente se inicia uma série de zombarias e caçoadas dos que se prestam a usufruir do tratamento doloroso.

Não é incomum encontrar-se algum taqueiro deitado na calçada, à beira da exaustão, esgotado de tanto desferir golpes em inúmeras pessoas, a ponto de ter cãimbras por conta do esforço excessivo e repetitivo. Nesse sentido, a qualidade da atuação não é medida pela lógica cartesiana ou através da comunicação racional, a qual é regulada na ação coerente dos indivíduos, mas pelo fluxo das mensagens transmitidas pelo corpo, o turbilhão das emoções que cruzam o espaço entre atuantes e espectadores.

Com o intuito de colocar o cosmo festivo em equilíbrio, seguindo de perto esse alvoroço, os caboclinhos vão também convocar "os seus" para a batalha que se avizinha. A cena rígida é percebida no ritmo marcial dos corpos, embalados por caixa e tambores, em compasso pouco apreciado pela maioria. Mestre Nininho, organizador do grupo dos caboclinhos, enfatiza que o grupo respeita a tradição e não altera o sentido do que é ser um caboclinho: mostrar força e impor respeito. Mestre de longa data dos caboclos, procura seguir à risca os preceitos que lhe foram ensinados pelos veteranos do brinquedo.

$\mathrm{O}$ cortejo final dos índios, momentos antes das embaixadas, é feito pelas ruas sempre em filas, simulando a dança do toré. De forma acelerada, vão à casa do cacique, o grande morubixaba, convocá-lo para reforçar o grupo ao combate. Com a indumentária adornada com penas de pavão, colares e estonteante cocar, ele se arma com arco e flecha saindo em disparada para pegar sua filha a fim de integrá-la ao grupo e volta em seguida para a perseguição aos lambe-sujos.

Sabendo que os caboclos estão apertando o cerco, o rei dos negros ordena que capturem a princesa dos caboclinhos e suas filhas, trazendo-as para dentro do quilombo, representado pela cabana. Nesse ato, desenrola-se uma embaixada entre os grupos; o rei dos caboclos envia alguns mensageiros pedindo a soltura de sua filha e ameaça o uso, se necessário, de violência para resgatar seus companheiros. Na praça principal, a multidão abre uma grande roda e, atenta, ouve o desfecho da transação que se estende com 


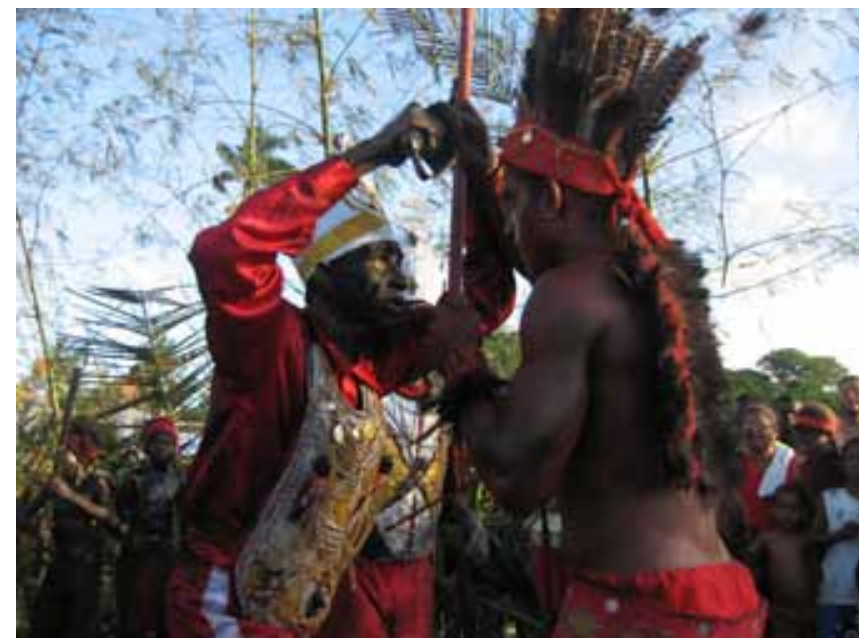

Figura 5.0 comba-

te final

Foto: Mesalas

Santos

achincalhes por parte dos lambe-sujos, culminando com a expulsão dos índios das terras dos negros. Sem surpresa, há intensa alegria misturada com alvoroço demonstrado pelos negros, que comemoram o aparente triunfo.

Com a notícia de que seus mensageiros indígenas haviam sucumbido à força escarnecedora dos negros, o cacique monta sua tropa para o confronto final. Nessa empreitada é auxiliado pelo Nêgo da forca, considerado traidor, que negociou terras com os silvícolas informando-lhes a localização do quilombo. Dispensado pelos índios, que não cumpriram o acordo, volta ao quilombo e logo é acusado de traição e, consequentemente, levado para a forca. Nesse momento, porém, ouvem-se os berros do negro: "meu senhor, os caboclos tão chegando!" E o rei, com dó, suspende a punição deixando-o no mastro, agora com a tarefa de vigiar o grupo.

O Largo do Quaresma, local de embate dos grupos, é tomado por todos os brincantes. Inicialmente, acontece de forma branda uma embaixada, em que os líderes, de forma tímida, se enfrentam com espadas. Com o auxílio dos taqueiros, que lutam em favor dos negros, os lambe-sujos vencem essa etapa. Os indígenas, afugentados, saem da cena, correndo desesperadamente sem direção pelas ruas da cidade.

Ovacionados pelos gritos efusivos que ecoam por toda a praça, os negros vão para dentro da cabana e com muita música e desenvoltura festejam a vitória momentânea. Esse instante é marcado pela tomada completa da praça central pelos lambe-sujos, cujas músicas contagiam todos os presentes, levando-os a arriscar-se numa aventura dramática, sendo impossível não fazer parte da turba completamente motivada pelas emoções.

Os indivíduos, completamente entorpecidos pela alegria contagiante que impulsiona os corpos em bailado desafiador, dimensionam seus corpos não de acordo com o caráter racionalizante das atividades ordinárias, mas colocando no espaço festivo a colisão das subjetividades. Aproveitando o momento de extravasamento, os caboclos se aproximam e tentam novamente destruir o quilombo. Através de mais uma embaixada, 
surgem os principais líderes dos lambe-sujos, tendo em Pai Joá, o auxílio espiritual para expulsar os nativos através de feitiços. Por fim, a tensão toma conta do ambiente festivo e todos entram em conflito generalizado. (Figura 5)

$\mathrm{O}$ combate final coloca os dois reis frente à frente; como num baile, eles simulam uma dança antes de se enfrentar, fazendo ecoar o choque das duas espadas. 0 combate generalizado resulta no esgotamento dos lambe-sujos, que saem derrotados e, mesmo sendo maioria esmagadora, veem sua cabana ser queimada pelo rei dos caboclos. 0 festejo atinge seu ponto final, quando, escoltados pelos caboclinhos, os lambe-sujos percorrem as ruas da cidade e, curvando-se diante das pessoas, amarrados a uma corda, pedem dinheiro para Ihes assegurar a liberdade.

As pessoas presentes se estimulam ao ver todo o alvoroço e subitamente se veem na encenação, provocando com insulto verbal e muito achincalhe. Em resposta, levam chicotadas dos taqueiros que não permitem tal insulto no espaço de combate. Por fim, depois de terminado o festejo, é comum as pessoas continuarem nas ruas, ouvindo músicas e festejando mais um lambe-sujo, melando-se com mel de cabaú, bebendo muitoe se permitindo muito achincalhe até o "corpo esmorecer, se prostar e cair no chão".

\section{CONCLUSÃO}

Festas são manifestações fundamentais de sociabilidade e momentos dos mais significativos da participação social. Em algumas delas, as minorias sociais não têm muita importância, em outras, participam aceitando a hierarquia da sociedade (micaretas, prévias carnavalescas) ou convertendo-se em protagonistas. Algumas festas poderiam ser chamadas de subversivas, como as de inversão: a festa dos loucos (BAKHTIN, 1999) (organizadas por abadias e representativas do mundo de cabeça para baixo) e o carnaval, conhecido como festa privilegiada do ritual de inversão social - protagonizada com abundância de alimentos e bebidas, bem como a utilização de sátira, maior liberdade sexual e uso de trajes de todos os tipos que, em alguns casos, pode desenvolver-se na inversão de gênero e posição social.

Discuti neste artigo alguns elementos importantes na abordagem descritiva da festa do Lambe-Sujo de Laranjeiras. Primeiro, a festa faz parte de um processo em curso, cujas etapas sucessivas são dramatizadas através das performances dos indivíduos. Enfatizei os dramas sociais que têm a importante função de espelho da sociedade, trazendoIhe momentos de reflexividade. Em segundo lugar, o festejo envolve a manipulação de símbolos (cor, música, comida, corpo) que constituem as unidades de menor atividade ritual e que por si só são portadores de significado. Em terceiro lugar, os significados dos símbolos são múltiplos, dando ênfase tanto à moralidade da ordem social como às necessidades emocionais do indivíduo.

Centrei especial atenção em torno daquilo que frequentemente é chamado de "atividade performática". Enfatizei o momento em que os brincantes dispostos no cenário festivo demonstram, através das performances culturais, sua história. Nesse sentido, os atores postos a desempenhar um papel dramatizam, através de "conflitos", sua própria estrutura social; definem e exprimem, de modo reflexivo, os dados essenciais da 
própria cultura. Estas dramatizações ocorrem, através de sequências rituais, como um processo, encenadas a partir de um "texto" cultural que se supõe "tradicional", mas que pode, todavia, apresentar inovações.

\section{REFERÊNCIAS}

BAKHTIN, Mikhail. A cultura popular na Idade Média e no Renascimento: o contexto de François Rabelais. 4 ed. São Paulo: Hucitec, 1999.

CASCUDO, Luís da Câmara. Prelúdio da cachaça: etnografia, história e sociologia da aguardente no Brasil. Rio de Janeiro: IAA, 1968.

DANTAS, Beatriz Góis. Vovó nagô, papai branco: usos e abusos da África no Brasil. Rio de Janeiro: Graal, 1988.

MAUSS, Marcel. Ensaio sobre a dádiva: forma e razão da troca nas sociedades arcaicas. In Sociologia e antropologia. V. II. São Paulo: Edusp, 1974.

Mesalas Ferreira Santos é graduado em ciências sociais (bacharelado e licenciatura) e mestre em sociologia pela Universidade Federal de Sergipe. Desenvolve pesquisas sobre festas tradicionais, com ênfase na análise de categorias como cultura popular, patrimônio cultural (material e imaterial), identidade, modernidade, drama e performance. Atualmente é docente da Faculdade Pio X, ministrando antropologia social e sociologia. 